\title{
"Assessment of energy potential of agricultural plants as a basis of bioenergetic management development in Ukraine"
}

\begin{tabular}{|c|c|}
\hline \multirow{5}{*}{ AUTHORS } & Alina Yakymchuk (D https://orcid.org/0000-0002-5038-5215 \\
\hline & R http://www.researcherid.com/rid/A-7576-2017 \\
\hline & Olha Pakharenko (D https://orcid.org/0000-0002-3172-8702 \\
\hline & Serhiy Shturkhetskyy (D https://orcid.org/0000-0003-4430-2628 \\
\hline & R http://www.researcherid.com/rid/F-6064-2016 \\
\hline ARTICLE INFO & $\begin{array}{l}\text { Alina Yakymchuk, Olha Pakharenko and Serhiy Shturkhetskyy (2018). } \\
\text { Assessment of energy potential of agricultural plants as a basis of bioenergetic } \\
\text { management development in Ukraine. Problems and Perspectives in } \\
\text { Management, 16(2), 331-340. doi:10.21511/ppm.16(2).2018.30 }\end{array}$ \\
\hline DOI & http://dx.doi.org/10.21511/ppm.16(2).2018.30 \\
\hline RELEASED ON & Monday, 11 June 2018 \\
\hline RECEIVED ON & Thursday, 11 January 2018 \\
\hline \multirow[t]{2}{*}{ ACCEPTED ON } & Tuesday, 15 May 2018 \\
\hline & $(\mathrm{coc}) \mathrm{EY}$ \\
\hline LICENSE & $\begin{array}{l}\text { This work is licensed under a Creative Commons Attribution } 4.0 \text { International } \\
\text { License }\end{array}$ \\
\hline JOURNAL & "Problems and Perspectives in Management" \\
\hline ISSN PRINT & $1727-7051$ \\
\hline ISSN ONLINE & $1810-5467$ \\
\hline PUBLISHER & LLC "Consulting Publishing Company "Business Perspectives" \\
\hline FOUNDER & LLC "Consulting Publishing Company "Business Perspectives" \\
\hline
\end{tabular}

NUMBER OF REFERENCES

49

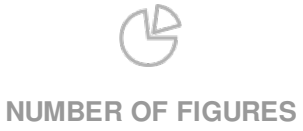

0

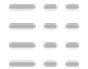

NUMBER OF TABLES

4

(C) The author(s) 2023. This publication is an open access article. 


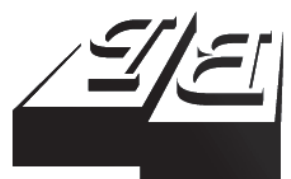

BUSINESS PERSPECTIVES

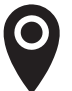

LLC "CPC "Business Perspectives" Hryhorii Skovoroda lane, 10, Sumy, 40022, Ukraine

www.businessperspectives.org

Received on: $11^{\text {th }}$ of January, 2018 Accepted on: $15^{\text {th }}$ of May, 2018

(C) Alina Yakymchuk,

Olha Pakharenko, Serhiy

Shturkhetskyy, 2018

Alina Yakymchuk, Doctor of Economic Sciences, Professor, National University of Water Management and Nature Resources Use, Ukraine.

Olha Pakharenko, Ph.D. (Economics), Associate Professor, National University of Water Management and Nature Resources Use, Ukraine.

Serhiy Shturkhetskyy, Ph.D. (Public Administration), Associate Professor, National University of Ostroh Academy, Ukraine.

\section{(c) (1)}

This is an Open Access article, distributed under the terms of the Creative Commons Attribution 4.0 International license, which permits unrestricted re-use, distribution, and reproduction in any medium, provided the original work is properly cited.
Alina Yakymchuk (Ukraine), Olha Pakharenko (Ukraine),

Serhiy Shturkhetskyy (Ukraine)

\section{ASSESSMENT OF ENERGY POTENTIAL OF AGRICULTURAL PLANTS AS A BASIS OF BIOENERGETIC MANAGEMENT DEVELOPMENT IN UKRAINE}

\begin{abstract}
Sustainable economic growth and increase in the level of population wellbeing, the diminution of energy dependence of Ukraine from the neighboring countries can only be achieved through the use of different types of biofuels, the practice of which is confirmed by the experience of other countries. One of the most promising types of fuel is agricultural plants, or rather the waste that remains after harvesting. The purpose of this study is to assess the energy potential of agricultural plants in Ukraine on the example of the Lviv region with an idea that it might reduce the energy dependence of Ukraine on Russia and other countries and will become a basis for improving the national energy management system. Assessment of the energy potential of agricultural plants was carried out on the example of the Lviv region. This assessment is based on all three components of the energy potential of agricultural plants (both theoretically and technically feasible and economically justified).
\end{abstract}

According to the results of calculations, waste of wheat, other grain crops and rape has the largest energy potential. In particular, the energy potential of agricultural biomass of the Lviv region makes theoretically possible (maximum) 2.1 million tons of fuel equivalent, technically achievable 0.915 million tons of fuel equivalent (including losses), and economically expedient (optimal) 0.74 million tons of fuel equivalent. The evidence revealed in the study confirmed the fact that Ukraine has sufficient energy potential use of agricultural crops. All these measures correspond to the state strategy for the development of the energy potential of Ukraine. Considerable attention is paid to the need to form an optimal management system for the use of energy potential of agricultural plants in Ukraine. Given the significant economic efficiency of agricultural wastes, the expediency of its use as biofuels has been substantiated. The most effective in energy terms are grain crops (wheat, barley), which should be preferred in the process of biomass creation.

\section{Keywords management, energy potential, agricultural plants, biomass, biofuel}

\section{JEL Classification Q10, Q40, Q42}

\section{INTRODUCTION}

Modern, competitive economies justify the use of energy potential of plants, which makes the basis for the economic development and ensures the safety of the environment of each country. Sustainable growth and the rise of living standards can be achieved through the introduction of advanced energy technologies that successfully compete in the global market. This is particularly relevant in the field of environmental protection, being an important issue in the country's financial and economic security, since it will save energy and reduce emissions of harmful substances into the environment. In this context, among the immensely important issues are the formation of an effective biofuel management system in Ukraine, the structural organization of the energy system elements in order to improve the state of 
the energy balance of the state, the increase of its financial and economic stability, the introduction of advanced technologies and development of new types of fuel. All this determined the relevance of the chosen topic of study and made it possible to sort out its subject, object, purpose and scientific novelty.

\section{LITERATURE REVIEW}

Among the scientists who appeared to be interested in the topic of the use of biofuel are Ladyka (2009), Deliatkina, Shkvarnytska (2006), Bevz (2007), Zabarnyi, Shurchkov (2002), Dolinskyi (2006), etc. who applied various methodologies in an attempt to assess the energy potential of agricultural plants, having introduced their own ones. Some scientists, including Davis, Boddey, Alves, Cowie, George, Ogle, Smith (2013) focused their attention on the development of energetic management system, having compared the experience of different countries in the context of energy potential. The aforementioned scholars mainly considered the possibilities of saving natural and financial resources. However, the issue of assessing the energy potential of agricultural plants was not given enough attention as plants should be considered separately depending on the region. All this served the basis for this study. The purpose of the study is to assess the energy potential of Ukrainian crops (on the example of the Lviv region), which will reduce the energy dependence of Ukraine on Russia and other countries and will serve as a basis for improving the national energy management system. There are also many revelations in the field of management; in particular, those of the foreign authors such as Gulshan (2011), Deslandes (2014), Holmes (2012), Harper (n.d.) mainly concern the methodological foundations of the development of the state management system, however, the energy component is investigated in them insufficiently.

According to Deviatkina and Shkvarnytska (2006), the future of energy management is directly related to the use of alternative energy sources, such as energy of biomass, sun, wind, seas and oceans, Earth's warmth, biological photosynthesis, etc. The authors give examples and introduce principles of how to operate electric power plants using alternative energy sources (AES). Moreover, they highlight the main environmental problems associated with the use of AES. This same idea found its support in the scientific works of Ladyka (2009), in which the author presents the results of a comprehensive study of the present state of the bioenergy potential of the forest-grassland and Polissya zones of Ukraine on the example of the Sumy region. In the paper, the author considers the main technologies of obtaining and using bioenergy resources, proposes methods for determining the economic efficiency and analyzes the environmental impacts of industrial production of bioenergy. Moreover, the paper contains prospects of energy consumption and development of bioenergy potential on the example of the Sumy region.

The idea to use agricultural plants as biofuels is supported in the work of Bevz (2007), where the author first analyzed the energy-ecological factor of Ukraine's economic development, its energy efficiency and features of the development of the fuel and energy complex. Unlike previous scientists, the author managed to form an concept of highly efficient power supply systems and management of energy-intensive installations of the mining and metallurgical complex, especially the technological re-equipment of thermal energy. In his work, Bevz (2007) paid special attention to the problems of increasing energy efficiency of the algorithms of central quality control of heat release from the suburban combined heat and pewer (CHP) plant, resource conservation in the electric power industry, as well as technological re-equipment of the control systems of the regimes of the combined power system of Ukraine. The author gives a general description of the use of non-traditional and renewable energy sources and analyzes the peculiarities of wind, solar, geothermal energy use, as well as sheds light on biomass energy, small rivers, offbalance sources of energy and energy resources of the environment. The author proposes ways to increase the efficiency of energy development of non-traditional and renewable sources; he considers relevant legislative, regulatory and normative support that makes his work outstandingly invaluable. This study is mainly focused on the technical side of the introduction of energy efficient management. 
As for the development of the energy management system in Ukraine, Zabarnyi and Shurchkov (2002) conducted a research, in which the authors, using their own developed methodology, calculated the promising and technically accessible potential of these energy sources, the expected power of heat and power generating units, fuel economy, which can be obtained in the conditions of their use, as well as defined increased technical-economic indicators of energy generating units using non-traditional energy sources. It was this work that enabled us to form a new vision for the development of the energy management system in Ukraine.

However, a comprehensive vision of the problem of energy management, namely the implementation of the national strategy for its development, was reflected in the work of Dolinskyi (2006). The author focused on energy efficiency, in particular, on the history of the problem, considering the dynamics of energy intensity indicators of the national economy of Ukraine, directions of potential energy saving measures in the branches of economy and indicators of their efficiency, as well as features of the Ukrainian fuel and energy complex, its fuel and energy balance and energy supply. The main tools of state energy saving management are considered in the paper. In particular, it mentions the state programs in this sphere, questions of standardization and rationing of fuel and energy resources expenses, the nature of control functions by the bodies of the State Inspectorate for Energy Conservation, as well as the features of energy conservation at the regional level. The positive point is that Dolinskyi (2006) analyzed the state of regulatory and legal maintenance of energy saving and perspective directions of its development, considering features of conducting of energy saving policy in the budget and communal sphere.

All these scientific researches have become the markers of the scientific search, having allowed to outline the main tasks of the work, to form the urgency, the subject and object of further research on the assessment of the energy potential of agricultural plants with the aim to develop the state system of energy management in Ukraine.

The works of foreign scientists made it possible to form a fundamental vision of the problem of en- ergy management. In particular, Davis, Boddey, Alves, Cowi, George, Ogle, Smith, and Mark (2013) developed energy management issues in terms of bioenergy cultures.

The scientific value of the authors' data performance is the fact that it allowed to assess the balance of greenhouse gases and the potential for lead management of seven different bioenergy extraction systems in temperate and tropical regions. According to the findings of these scientists, the priority of land use, harvesting technology, harvesting time and fertilization are among the main managerial considerations that can change the bioenergy balance of greenhouse gases from positive to negative or vice versa. Despite the fact that potential for lead management is essential for many growing systems, there are some species, e.g. soybeans, which have a low potential for bioenergy production. However, high-performance bioenergy crops (such as corn, sugarcane, miscanthus and rapidly growing tree species) have a number of benefits. One can not but agree with this opinion. The importance of scientific works of foreign authors increases also due to the fact that they consider the system of management of bionergic potential in the complex with its development. In particular, this thesis is supported by such scholars as Dixon, Pagiola (2000), Kluster (1991), Macko (1937), Middleton and Hawkins (1998), Mieczkowski (1995), Panek (1939), McNeely and Harrison (1994).

The purpose of the paper is to assess the current energy potential of agricultural plants in Ukraine on the example of the Lviv region. It appears to be important to find new ways of its economic evaluation and justification of of the ways to develop the national energy management system.

\section{RESULTS}

The issue of development of the energy management system is becoming increasingly relevant in Ukraine, especially in view of the rich experience of the developed countries of the world in this area. Energy management is usually understood as an activity aimed at ensuring the rational use of fuel and energy resources at an enterprise or in municipalities, which can significantly optimize 
energy consumption (Main Statistical Office in Lviv region; Institute of local development, 2013; Dubrovin, Holub, Drahniev et al., 2013; State Statistics Committee of Ukraine, 2012; Energy strategy of Ukraine until 2030; Ladyka, 2009; Deviatkina \& Shkvarnytska, 2006; Bevz et al., 2007; Zabarnyi \& Shurchkov, 2002; Shydlovskyi, 2001; Dolinskyi et al., 2006; Davis, Sarah et al., 2013; Sheliag-Sosonko, Andrienko, \& Udra, 1979; Verkhovna Rada of Ukraine, 2004; Thorsell, 1982).

However, according to the authors of this study, this concept is much wider.

Unlike the traditional understanding of the term "energy management", the author's one relies upon the fact that it is a complex system of state organizational mechanism, which should be based on stimulating economic instruments for the introduction of innovative types of fuels with restorative potential, especially of agricultural plants (wheat, rye, corn, etc.). Such definition will allow to from an updated methodology of the state power potential management system as the basis for the development of the energy management system.

Ukraine belongs to energy-deficit countries, which meets its fuel and energy needs at the expense of its own resources by less than $50 \%$. The energy intensity of the gross domestic product in Ukraine is now more than twice the energy intensity of the one of industrialized countries and continues to grow. Therefore, the strategic line of state policy on economic and social development is increasing energy efficiency, which provides high economic efficiency (Energy strategy of Ukraine until 2030). This policy is implemented through the development of new energy-saving, low-waste and nonwaste technologies, efficient systems and means of control over energy consumption and environmental protection from pollution, organization of integrated energy and economic management (Verkhovna Rada of Ukraine, 2004; Mieczkowski, 1995; Kutsyk, Vasyltskiv, Sorokivskyi, \& Sorokivska, 2015; Deslandes, 2014; Holmes \& Leonard, 2012).

Implementation of such policy is impossible in the absence of specialists in the field of energy saving who can develop and implement the directions of development of society and economy, aimed at stabilization and reduction of energy consumption. Therefore, the training system of engineering and scientific personnel should be focused on such development of energy and production of the future, which provide the optimum amount of generation, distribution and consumption of energy. So far, a specialist in energy management should meet these requirements. To do this, they must have a broad basic, scientific and practical training, a deep knowledge of the basics of energy; be able to make optimal managerial decisions on effective energy consumption, use advanced methods of forecasting, planning, accounting, control and analysis of energy consumption of production systems; to carry out consulting services for the development and implementation of energy saving programs and the launch of the energy management system; be able to conduct inspection, examination and energy auditing of production systems on energy efficiency, integrated study of the energy market; assessment and formation of energy policy; to have the basics of market economy and economic strategy, economic thinking, ability to business communication, entrepreneurship and commercial activity; have skills in educational and organizational work (Dolinskyi et al., 2006; JUCN, 1994; Holmes \& Leonard, 2012; Melling, Joseph; McKinlay, Alan, 1996; Stoner \& James, 1995; Yakymchuk, 2014).

The issue of assessing the energy potential of territories makes scientific and practical interest. In this study, the authors propose to determine the energy potential of the state in three directions: the general (estimated, maximum, which can be achieved by burning all agricultural waste), technically feasible (which can be achieved when the losses of agricultural crops during transport, biting straw, etc. are taken into account) and economically expedient (optimal) for each region (district) of Ukraine being considered separately. Given the obtained regional values, it is necessary to calculate the bioenergy potential of Ukraine by the method of summation. In this study, the calculation is done on the example of the Lviv region. Based on the statistical data for 2016 received from the Lviv Regional Department of Statistics the calculation of the energy potential of primary agricultural wastes on an example of grain crops in this paper is based on the statistical values of gross collections of wheat, barley, other grain crops (1428.84 thousand tons), 
Table 1. Production of the main crops (in centners) in the Lviv region for the period 2010-2016

Source: Author's summing up on the basis of Main Statistical Office in Lviv region, State Statistics Committee of Ukraine (2012).

\begin{tabular}{c|c|c|c|c|c|c|c|c}
\hline Year & $\begin{array}{c}\text { Cereals and legumes } \\
\text { (weight after } \\
\text { harvesting) }\end{array}$ & $\begin{array}{c}\text { Sugar } \\
\text { beet }\end{array}$ & Sunflower & Soy & $\begin{array}{c}\text { Rape and } \\
\text { colza }\end{array}$ & Potato & Vegetables $\begin{array}{c}\text { Fruits and } \\
\text { berries }\end{array}$ \\
\hline 2010 & 6226.5 & 5295.1 & 2.1 & 43.9 & 972.2 & 12587.9 & 4118.9 \\
\hline 2011 & 9616.0 & 6737.5 & 17.5 & 12.7 & 863.2 & 18248.6 & 4696.3 & 901.1 \\
\hline 2012 & 10656.6 & 8344.7 & 48.3 & 174.2 & 1223.7 & 18307.7 & 4712.7 & 938.6 \\
\hline 2013 & 11861.2 & 6537.4 & 184.6 & 273.6 & 1537.2 & 15734.2 & 4567.0 & 972.5 \\
\hline 2014 & 14218.9 & 7808.2 & 288.5 & 484.5 & 1572.0 & 17089.3 & 4800.4 & 990.4 \\
\hline 2015 & 13663.3 & 5829.7 & 277.9 & 760.9 & 1412.0 & 16224.7 & 4835.4 & 1067.2 \\
\hline 2016 & 14288.4 & 6778.5 & 676.2 & 1114.4 & 1183.3 & 16188.6 & 5056 & 1076,3 \\
\hline
\end{tabular}

rape (118.33 thousand tons), corn for grain (505.6 thousand tons), sunflower (67.62 thousand tons) in the Lviv region (Table 1).

The calculations are based on a methodology for assessing the energy potential of biomass, proposed by the United States Agency for International Development (USAID) (Institute of local development, 2013). The main purpose of this technique is to substantiate the technical and economic efficiency of the use of agricultural crop waste as biofuels. Currently, the search for alternative fuels in the context of a shortage of fuel and energy resources is becoming more urgent and is capable of ensuring a higher level of energy independence of Ukraine from neighboring countries.

This assessment of technically achievable energy potential of straw of technical and cereal crops is carried out on the basis of the following assumptions (Thorsell, 1982; National Research Council, National Academy of Sciences of USA, 2004; Whittaker, 1972; Williams, Humphrics, \& Araujo, 1999; Yakymchuk, 2013, 2014):

1) calculation is made on the main types of crops, namely wheat, other grain crops (rye, barley, oats, millet), corn for grain, industrial crops (soybeans, sunflower), cereals (buckwheat, rice), leguminous (pea);

2) the straw obtained is pressed and burned in boiler houses, heat generating units, which means that only heat energy for the heat supply system is produced.

The volume of waste is calculated using the coefficients set for different crops (Table 2). In particular, such coefficients are established as the ratio of dry weight of terrestrial residues to the mass collected with the moisture content of the soil. Based on the data obtained from the Ukrainian Academy of Agrarian Sciences and other sources (Dubrovin, Holub, Drahniev et al., 2013; State Statistics Committee of Ukraine, 2012; Energy strategy of Ukraine until 2030), the volume of straw, for example, for wheat can be calculated as follows: 1428.84 thousand tons ' $1.0=1428.84$ thousand tons. For other cultures, we expect the volume of waste to be similar in the same way as the product of the statistical values of the yield of the main types of crops in thousand tons, as shown in Table 1, and in accordance with the set values for straw output.

Table 2. The value of the straw output coefficient for cereals

Source: Compiled by the author according to Institute of local development (2013)

\begin{tabular}{c|l|c}
\hline No & $\begin{array}{c}\text { The name of the } \\
\text { agricultural crop }\end{array}$ & $\begin{array}{c}\text { The value of the straw } \\
\text { output factor, Kr }\end{array}$ \\
\hline 1 & Wheat & 1.0 \\
\hline 2 & Barley & 0.8 \\
\hline 3 & Other cereals & 1.0 \\
\hline 4 & Rape & 2.0 \\
\hline 5 & Corn for grain & 1.3 \\
\hline 6 & Sunflower & 1.9 \\
\hline
\end{tabular}

The calculated waste volume for the abovementioned crops is theoretically feasible potential of biomass available for energy production. The technically feasible and economically feasible potential will be determined with the use of the factors of technical accessibility and energy use.

The general formula for assessing the economic potential of waste products of a particular agricultural crop is as follows (Institute of local development, 2013): 


$$
P_{e}=C_{r} \cdot K_{r} \cdot K_{t} \cdot K_{e} \cdot K_{c e},
$$

where $P_{e}$ - economically feasible potential, thousand tons; $C_{r}-$ gross collection of agricultural crop, thousand tons; $K_{r}$ - the coefficient of waste that differs in various types of crops; $K_{t}$ - the coefficient of technical availability of agricultural waste, which characterizes the amount of straw that can be obtained under the existing technology of harvesting crops. According to the data of the State Statistics Committee of Ukraine, this indicator is adopted as 0.8 for the natural conditions of Ukraine (Dubrovin, Holub, Drahniev et al., 2013); $K_{e}$ - utilization rate of waste; $K_{c e}-$ coefficient of conversion in conventional fuel.

If in the formula (1) the coefficient of technical availability of agricultural waste $K_{t}$ and utilization rate of waste $K_{e}$ are not taken into account, theoretically possible biomass potential can be found. If the coefficient of technical use $K_{e}$ is not considered, technically desirable potential can be figured out. If the coefficient $K_{c e}$ is not taken into account (coefficient of conversion in conventional fuel), all the figures are to be got in physical units (thousand tons). As the research shows, the obtained values of the theoretical, technical and economic potential differ significantly among themselves. In particular, if the theoretical potential is taken for $100 \%$, then, the technical is $60-80 \%$ of the theoretical, and the economic $-60-80 \%$ of the technical.

The coefficient of energy use of straw $K_{e}$ has its own peculiarities. It depends on the needs of agriculture. In particular, part of it is spent on the needs of cattle (large cattle) - on litter and roughage; part is used as organic fertilizer and part for energy production. Thus, the size of the energy utilization rate of straw $K_{e}$ varies from year to year, depending on the ratio of grain crop yields and cattle and pigs population. Calculation of the value of this indicator for Lviv region in 2016 is as follows:

$$
K_{e}=\frac{H_{c}}{Q_{c}},
$$

$H_{c}$ - volume of excess straw, which can be used for energy production, thousand tons; $Q_{c}$ - total volume of technically accessible straw of grain crops, thousand tons.

Excess straw that can be used to produce energy is calculated as the difference between the total volume of technically available straw of cereals and the amount of straw needed for cattle needs. Using the data from official statistics on the number of livestock of cattle in 2016 (203.4 thousands of heads) and pigs (348.6 thousands of heads) (Main Statistical Office in Lviv region), the norm of straw consumption per animal (correspondingly, 0.9 tons, $365 \mathrm{~kg}$ per year) (Institute of local development, 2013, p. 13), the expected amount of excessive straw that can be used for energy production can be calculated as follows:

$$
\begin{aligned}
& H_{c}=1428.84 \text { thousand tons }- \\
& (203.4 \text { thousands of heads } \cdot 0.9+ \\
& +348.6 \text { thousands of heads } \cdot 0.365)= \\
& =1118.541 \text { (thousand tons). }
\end{aligned}
$$

\begin{tabular}{|c|c|c|c|}
\hline No & $\begin{array}{l}\text { The name of the } \\
\text { agricultural crop }\end{array}$ & Heat of combustion (MJ / kg) & $\begin{array}{l}\text { The value of the conversion factor } \\
\text { in conventional fuel } K_{c e}\end{array}$ \\
\hline 1 & Wheat & 17.2 & 0.59 \\
\hline 2 & Barley & 15.9 & 0.54 \\
\hline 3 & Other cereals & 15.0 & 0.51 \\
\hline 4 & Rape & 17.5 & 0.60 \\
\hline 5 & Corn for grain & 13.7 & 0.47 \\
\hline 6 & Sunflower & 13.7 & 0.47 \\
\hline 7 & Sunflower husk & 16.0 & 0.55 \\
\hline
\end{tabular}

Thus, the coefficient of energy use of straw $K_{e}$ is:

$$
K_{e}=\frac{1118.541 \text { thousand tons }}{1428.84 \text { thousand tons }}=0.78 \text {. }
$$

Table 3. Calculation of the coefficient of conversion factor into conventional fuel

Source: Calculated by the author on the basis of Institute of local development (2013). 
Table 4. Calculation of energy potential $\left(\mathrm{P}_{\mathrm{e}}\right)$ of agricultural waste in the Lviv region for 2016

Source: Author's calculation.

\begin{tabular}{|c|c|c|c|c|c|c|c|c|c|}
\hline Crop & $\begin{array}{c}\text { Gross } \\
\text { amount, } \\
\text { thousand } \\
\text { tons, } C_{r}\end{array}$ & $\begin{array}{c}\text { Straw } \\
\text { output } \\
\text { ratio, } K_{r}\end{array}$ & $\begin{array}{c}\text { Theoretical } \\
\text { potential, } \\
\text { thousand } \\
\text { tons }\end{array}$ & $\begin{array}{c}\text { Coefficient } \\
\text { of conversion } \\
\text { factor in } \\
\text { conventional } \\
\text { fuel, } K_{t} \\
\end{array}$ & $\begin{array}{c}\text { Theoretical } \\
\text { potential, } \\
\text { thousand } \\
\text { tons }\end{array}$ & $\begin{array}{c}\text { The } \\
\text { coefficient } \\
\text { of } \\
\text { technical } \\
\text { availability } \\
\text { of waste, } K_{t}\end{array}$ & $\begin{array}{c}\text { Technical } \\
\text { capacity, } \\
\text { thousand } \\
\text { tons }\end{array}$ & $\begin{array}{c}\text { Coefficient } \\
\text { of energy } \\
\text { use of } \\
\text { straw, } K_{e}\end{array}$ & $\begin{array}{c}\text { Economic } \\
\text { capacity, } \\
\text { thousand } \\
\text { tons, } P_{\mathrm{e}}\end{array}$ \\
\hline Wheat & 807.28 & 1.0 & 807.28 & 0.59 & 476.29 & 0.8 & 381.03 & 0.78 & 297.20 \\
\hline Barley & 261.77 & 0.8 & 209.42 & 0.54 & 113.08 & 0.8 & 90.46 & 0.78 & 72.36 \\
\hline $\begin{array}{l}\text { Other } \\
\text { cereals }\end{array}$ & 359.79 & 1.0 & 359.79 & 0.51 & 183.49 & 0.8 & 146.79 & 0.78 & 114.49 \\
\hline Rape & 118.33 & 2.0 & 236.66 & 0.60 & 141.99 & 0.8 & 113.59 & $1.0^{*}$ & 113.59 \\
\hline $\begin{array}{l}\text { Corn for } \\
\text { grain }\end{array}$ & 276.98 & 1.3 & 360.07 & 0.47 & 169.23 & 0.8 & 135.38 & $0.7^{*}$ & 94.76 \\
\hline Sunflower & 67.62 & 1.9 & 128.47 & 0.47 & 60.38 & 0.8 & 48.30 & $1.0^{*}$ & 48.30 \\
\hline Total & 1891.77 & - & 2101.69 & - & 1144.46 & - & 915.55 & - & 740.70 \\
\hline
\end{tabular}

Note: ${ }^{\star}$ Data are taken from Institute of local development (2013).

According to the conservative approach, the value is divided in half (since part of the straw remains as organic fertilizer): $0.78 / 2=0.39$.

In Table 3 the value of the conversion factor in conventional fuel is given. It is the ratio of the heat of combustion of a certain type of biomass $(\mathrm{MJ} / \mathrm{kg})$ to the heat of combustion of the conventional fuel $(29.3 \mathrm{MJ} / \mathrm{kg}$ ) (Institute of local development, 2013).

Since straw is one of the most important sources of biofuels in Ukraine, which, along with other biomass types, does not lead to an increase in greenhouse gas emissions of carbon dioxide into the atmosphere, it has a significant energy potential. Calculations on the energy potential of different types of crops in the Lviv region that are made in this paper are summarized in Table 4.

So, the issues of energy management in Ukraine are becoming more and more urgent. This term under is traditionally considered as an activity aimed at ensuring the rational use of fuel and energy resources, based on obtaining energy-technological information by recording, conducting typical energy-technological measurements and inspections, analyzing the efficiency of the use of fuel and energy resources and introducing energy-saving measures. Currently, energy management is a mandatory element in the structure of any enterprise, which aims to reduce energy consumption through their effective use. Energy management is an effective tool for increasing the competitiveness of the enterprise by reducing the cost of purchasing energy resources.

Implementation of the energy management system at the enterprise is a widespread international practice. Since 2011, the InternationalOrganization for Standardization has implemented the ISO 50001 "Energy Management" standard. This standard is intended to provide organizations that have decided to make energy efficiency part of their management system. The standard covers the following actions (Mellin \& McKinlay, 1996):

to assist enterprises in the process of organization of more efficient use of existing energy-intensive assets;

- to create transparency in the use of energy resources;

- to facilitate the implementation of advanced energy management and strengthening of effective energy management skills;

to assist in the assessment of objects in terms of energy efficiency and prioritization of the introduction of new energy-saving technologies;

to ensure the basis for improving energy efficiency throughout the production chain;

- to enable the possibility of integration with other organizational management systems, such as environmental management and labor protection. 
ISO50001 providesthebasicsthat allow organizations (Davis, Sarah, Boddey et al., 2013; Sheliag-Sosonko, Andrienko, \& Udra, 1979; Verkhovna Rada of Ukraine, 2000, 2004; Dixon \& Pagiola, 2000; Phillips, 1998; JUCN, 1994; Kluster, 1991):

- to develop a policy on energy saving;

- to set goals and targets for achieving the goals of energy saving policy;

- to use data to better understand energy consumption and make decisions on these issues;
- to measure the level of energy efficiency increase;

- to carry out an analysis of the effectiveness of the implementation of energy saving policies;

- to constantly improve the work of the energy management system at the enterprise.

Today, certification for compliance with the requirements of ISO 50001 is a significant step forward in the way of energy efficient manufacturing in Ukraine.

\section{CONCLUSION}

The author's interpretation of the term "energy management" as an integrated system of state organizational mechanism, which should be based not on policy-making methods, but on stimulating economic instruments and the introduction of innovative types of fuels with reducing potential, is widely examined in this study. Such definition will allow to form an updated methodology of the state energy potential management system as the basis for the development of its financial and economic security. The renewable energy sources, such as the sun, wind, and especially the plant potential, will provide an economic component of the development of society in accordance with the concept of sustainable development, and, thus, will have ecological strategic importance and will contribute to the formation of an effective system of management of the energy potential of Ukraine, especially in the current conditions of military and political instability.

As calculations show, the largest economic potential of biofuels is the waste of such crops as wheat, other grain crops and rape. The economic potential is much lower than the theoretical and technical potential of biofuels, as it involves further losses in preparation for combustion (transportation, drying, storage, stinging, etc.). It was confirmed by the calculations that the energy potential of vegetative agricultural biomass of the Lviv region in 2016 was: theoretically possible -2.1 million tons of fuel equivalent, technically achievable -0.915 million tons of fuel equivalent, and economically expedient -0.74 million tons.

In conclusion, the expediency of attracting waste from agricultural plants of Lviv region as biofuels is substantiated, given the significant economic efficiency. The most favorable culture in terms of energy is the grain crops (wheat, barley), which should be preferred to create biomass. Others, such as corn, are economically inappropriate, because additional costs are required for pre-drying the stems of the plant before burning.

Consequently, the study confirmed the fact that in the Lviv region, there is sufficient energy potential of biomass to use it for the energy needs of both the region (district) and the state as a whole. All these measures correspond to the state strategy for the development of the energy potential of Ukraine. The calculation methodology is typical and should be used to assess the energy potential of agricultural plants in other regions of Ukraine. The assessment of the energy potential of biomass will create the basis for the formation of an effective energy management system in Ukraine. 


\section{REFERENCES}

1. Baranovych, D. B., Krychkovska, A. M., Zhurakhivska, L. R., Lubinets, L. I., Shved, O. V., Gubytska, I. I., Novikov, V. P. (2012). Dictionary od terms in Management, Marketing, Pharmacy and Biotechnology for students of the Institute of Chemistry and Chemical technologies in the educational area 6.051401 "Biotechnology", 6.120201 "Pharmacy" (128 p.). Lviv: Publishing Lviv. politechniky.

2. Barrett, R. (2003). Vocational Business: Training, Developing and Motivating People. Cheltenham: Nelson Thornes.

3. Bevz, S. M. et al. (2007). Energy Efficiency and Renewable Energy (560 p.). Kyiv: Ukr. entsyklop. znannia.

4. Davis, Sarah C., Boddey, Robert M., Alves, Bruno J. R., Cowie, Annette L., George, Brendan H., Ogle, Stephen M., Smith, Pete; van Noordwijk, Meine; van Wijk, Mark T. (2013). Management swing potential for bioenergy crops. $G C B$ Bioenergy, 5(6), 623-638. Retrieved from http://onlinelibrary.wiley.com/ doi/10.1111/gcbb.12042/abstract

5. Deslandes, G. (2014). "Management in Xenophon's Philosophy: a Retrospective Analysis". Paper presented at 38th Annual Research Conference, Philosophy of Management, 2014, July 14-16, Chicago.

6. Deviatkina, S. S., Shkvarnytska, T Yu. (2006). Alternative sources of energy: textbook (92 p.). Kyiv.

7. Dixon, J., Pagiola, S. (2000). Local Costs, Global Benefits: Valuing Biodiversity in Developing Countries. Environmental Department, The World Bank, 12-34.

8. Dolinskyi, A. A. et al. (2006). Energy saving strategy in Ukraine: analytical and referential materials: in 2 volumes. V. 1. General principles of energy saving (508 p.). Kyiv: Akademperiodyka.

9. Dubrovin, V. O., Holub, H. A., Drahniev, S. V. et al. (2013). Method of a generalized assessment of the technically feasible energy potential of biomass (25 p.). Kyiv: "Viol-print" enterprise.

10. Energy strategy of Ukraine until 2030: decree of the Cabinet of Ministers of Ukraine from 24.07.2013 No. 1071. Retrieved from http://zakon3.rada.gov.ua/ laws/show/n0002120-13

11. Fayol, H. (1966). Administration industrielle et générale - prévoyance organization-commandment, coordination - contrôle. Paris: Dunod.

12. Frank, Prabbal (2006). Prabbal Frank attempts to make a subtle distinction between management and manipulation: People Manipulation: A Positive Approach (2nd ed.). New Delhi: Sterling Publishers Pvt. Ltd. (published 2009).

13. Gulshan, S., Prasad, L. (2014). Management Principles and Practices. Excel Books India.

14. Harper, Douglas (2015). "Management". Online Etymology Dictionary.

15. Holmes, Leonard (2012). The Dominance of Management: $A$ Participatory Critique. Voices in Development Management. Ashgate Publishing, Ltd.

16. Institute of local development (2013). Energy potential of Mirgorod district and assessment of available calculation methods: Report in the framework of cooperation with the United States Agency for International Development (USAID) (82 p). Kyiv: IMP

17. Jones, Norman L. (2013). Chapter Two: Of Poetry and Politics: The Managerial Culture of SixteenthCentury England. In Kaufman, Peter Iver (Ed.), Leadership and Elizabethan Culture. Jepson Studies in Leadership (p. 18). Palgrave Macmillan.

18. JUCN (1994). JUCN Guidelines for Protected Area Management Categories. Gland, Switzerland and Cambridge, UK.

19. Kluster, J. (1991). Ecotourism and Recourse Conservation. A Collect of Papers from 2nd International Symposium: Ecotourism and
Resource Conservation, November 1990.

20. Kutsyk, P. O., Vasyltskiv, T. G. Sorokivskyi, V. M., Sorokivska, M. V. (2015). Insurance Management: textbook (243 p.). Lviv: Lviv. komerts. akad.

21. Kuzmin, O. Ye. et al. (2012). Management and entrepreneurship of Ukraine: the stages of formation and the problems of development (324 p.). Lviv: Publishing Lviv. politechnyky.

22. Kuzmin, O. Ye., Mala, N. T., Melnyk, O. G., Sanina, O. R. (2012). Management: Textbook (240 p.). Lviv: Publishing Lviv. politechnyky.

23. Ladyka, V. I. (Ed.) (2009). Bioenergy potential of forest-steppe and Polissya zones of Ukraine and prospects for its use: monograph (304 p.). Sumy: Univ. kn.

24. Macko, S. (1937). Roslinnosc proektowanych reserwatow na Wolyniu. Ochr. Przyr., 17, 111-185.

25. Main Statistical Office in Lviv region (n.d.). Production of basic crops in Lviv region: Regional statistics department of Ukraine in the Lviv region. Retrieved from http://www. lv.ukrstat.gov.ua/ukr/themes/04/ theme_04.php?code $=04$

26. McNeely, J. A., Harrison, J., \& Dingwall, P. (1994). Protecting Nature: Regional Reviews of Protected Areas. IUCN (402 p.). Gland, Switzerland and Cambridge, UK.

27. Melling, Joseph; McKinlay, Alan (Eds.) (1996). Management, Labour, and Industrial Politics in Modern Europe: The Quest for Productivity Growth During the Twentieth Century. Edward Elgar.

28. Middleton, V., \& Hawkins, R. (1998). Sustainable Tourism: A Marketing Perspective (266 p.). Butterworth/Heinemann.

29. Mieczkowski, Z. (1995). Environmental Issues of Tourism and Recreation (496 p.). Lanham, MD University Press of America, Inc.

30. Morushko, O. O. (2014). Personnel Management: textbook (173 p.). Lviv: Nat. University "Lviv. politechnika". 
31. National Research Council, National Academy of Sciences of USA (2004). Valuing ecosystem services. Toward better environmental decision-making. Report in brief (67 p.). Committee on Assessing and Valuing the Services of Aquatic and Related Terrestrial Ecosystems.

32. Panek, J.(1939). Roslinnosc stepowa i naskalna lessowego Wolynia. Rocz. Wolynski, Rowne, 26-66.

33. Phillips, A. (Ed.) (1998). Economic Values of Protected Areas: Guidelines for Protected Areas Managers (72 p.). JUCN.

34. Pietkov, S. V. (2005). The problem of rational use of time in management as the basis of effective management in the organs of internal affairs of Ukraine. Law and Security, 4(3), 9-82. Retrieved from http://nbuv.gov.ua/UJRN/ Pib_2005_4_3_23

35. Sheliag-Sosonko, Yu. R. Andrienko, T. L., Udra, I. H. (1979). Vegetation of "Nadsluchanska Switzerland" - valuable booklet of nature of Polissya. Ukr. botan. zhurn., 6, 35-38.

36. Shydlovskyi, A. K. (Ed.) (2001). Fuel and energy complex of Ukraine on the threshold of the third millennium (400 p.). Kyiv: Ukr. entsyklop. znannia.
37. State Statistics Committee of Ukraine (2012). Vegetation in Ukraine: Statistic collection $(108$ p.). Kyiv.

38. Stoner, James A. F. (1995). Management (6th ed.). Englewood Cliffs, New Jersey: Prentice Hall, Inc.

39. Taylor, L. R., Kempton, R. A., Woiwod, I. P. (1976). Diversity Statistics and Log-Series Model. J. Anim. Ecol., 45, 255-271.

40. Thorpe, J., Godwin, R. (1999). Threats to Biodiversity in Saskatchewan (75 p.). Saskatoon: Saskatchewan Research Council.

41. Thorsell, J. W. (1982). Evaluating effective management in protected areas: An application to Arusha national Parks, Tanzania. Paper presented at World National Parks Congress, Bali, JUCN Commission on National Parks and Protected Areas.

42. Tulenkov, M. V., Chuvardnytskyi, O. G., Shaigorodskyi, Yu. Zh. (2012). Modern management (theories, concepts, models): textbook (376 p.). Kyiv: Ukrainian Center of Political Management.

43. Verkhovna Rada of Ukraine (2000). About the National Program for the Formation of the National
Ecological Network of Ukraine for 2000-2015: Law of Ukraine from 21 September 2000. Bulletin of the Verkhovna Rada of Ukraine, 47, 405.

44. Verkhovna Rada of Ukraine (2004). About ecological network: Law of Ukraine from 24 June 2004. No. 1864-IV. Bulletin of the Verkhovna Rada of Ukraine, 45, 502.

45. Whittaker, R. H. (1972). Evolution and Measurement of Species Diversity. Taxon., 21, 213-251.

46. Williams, P., Humphrics, C., Araujo, M. (1999). Mapping Europe Biodiversity (129 p.). London: Nat. Hist. Museum.

47. Yakymchuk, A. (2013). Innovative Mechanisms of Biodiversity's Maintainance. Science and Education a New Dimension. Humanities and Social Science, 12I(2), 110-113.

48. Yakymchuk, A., Mykytyn, T., Valyukh, A. (2017). Management of Protected Areas of Ukraine's Polissia: International Experience. Problems and Perspectives in Management, 15(1), 183-190.

49. Zabarnyi, G. M., Shurchkov, A. V. (2002). Energy potential of non-traditional energy sources of Ukraine (210 p.). Kyiv. 